\title{
Rangeland degradation assessment: a new strategy based on the ecological knowledge of indigenous pastoralists
}

\author{
Bahareh Behmanesh ${ }^{1}$, Hossein Barani ${ }^{2}$, Ahmad Abedi Sarvestani ${ }^{3}$, Mohammad Reza Shahraki ${ }^{4}$, and \\ Mohsen Sharafatmandrad ${ }^{5}$ \\ ${ }^{1}$ Department of Rangeland \& Watershed Management, Faculty of Agricultural Sciences and \\ Natural Resources, Gonbad Kavous University, Gonbad Kavous, Iran \\ ${ }^{2}$ Department of Rangeland \& Watershed Management, Gorgan University of Agricultural Sciences \\ and Natural Resources, Gorgan, Iran \\ ${ }^{3}$ Faculty of Agricultural Extension and Education, Gorgan University of Agricultural Sciences \\ and Natural Resources, Gorgan, Iran \\ ${ }^{4}$ Saee Institute of Higher Education, Gorgan, Iran \\ ${ }^{5}$ Natural Resources Department, University of Jiroft, Jiroft, Iran
}

Correspondence to: Mohsen Sharafatmandrad (mohsen.sharafatmandrad@ujiroft.ac.ir)

Received: 8 September 2015 - Published in Solid Earth Discuss.: 30 October 2015

Revised: 10 March 2016 - Accepted: 10 March 2016 - Published: 18 April 2016

\begin{abstract}
In a changing world, the prevalence of land degradation is becoming a serious problem, especially in countries with arid and semi-arid rangelands. There are many techniques to assess rangeland degradation that rely on scientific knowledge but ignore indigenous people. Indigenous people have accumulated precious knowledge about land management through generations of experience. Therefore, a study was conducted to find out how indigenous people assess rangeland degradation and how their ecological knowledge can be used for rangeland degradation assessment. Interviews were conducted with the pastoralists of two sites (Dasht and Mirza Baylu), where part of both areas is located in Golestan National Park (north-eastern Iran). A structured questionnaire was designed based on 17 indicators taken from literature and also primary discussions with pastoralists in order to evaluate land degradation. A qualitative Likert five-point scale was used for scoring rangeland degradation indicators. The results revealed that pastoralists pay more attention to edaphic indicators than to vegetative and other indicators. There were significant differences between the inside and outside of the park in terms of rangeland degradation indicators for both sites. The results show that the rangelands outside of the park in both sites were degraded compared to those inside of the park, especially in the areas close to villages. It can be concluded that pastoralists have a wealth of
\end{abstract}

knowledge about the vegetation and grazing animal habits that can be used in rangeland degradation assessment. It is therefore necessary to document their ecological indigenous knowledge and involve them in the process of rangelanddegradation assessment.

\section{Introduction}

Rangelands are the largest terrestrial ecosystems on the Earth, covering close to $40 \%$ of the world landscape, of which more than $80 \%$ located in arid and semi-arid areas (Branson et al., 1981). Soil is the most important component of rangeland ecosystems. It has an interdisciplinary nature and is associated with biodiversity, biogeochemical cycling, hydrology, human health and social sciences (Brevik et al., 2015). Rangeland soils moreover offer services to the human societies and make the Earth system stable (Keesstra et al., 2012; Berendse et al., 2015). Unfortunately, rangelands have undergone (and continue to undergo) rapid transformations as a result of factors such as overgrazing, deforestation, woody-plant encroachment, and invasion by non-native plant species (Wilcox and Thurow, 2006). Each of these factors has led to a reduction in the quantity and/or nutritional quality of the vegetation available for grazing; this is known as "range- 
land degradation" (IFAD, 2003). This also resulted in higher soil and water losses (Cerdà, 1998; Kröpfl et al., 2011; Li et al., 2013).

It is believed that livestock grazing is associated with rangeland degradation. Grazing is the most important factor affecting vegetation and soil in all rangelands of the world, having a critical impact on rangeland biodiversity and species composition (Sharafatmandrad et al., 2014; Angassa, 2014), biological groups (Sharafatmandrad et al., 2014; Tarhouni et al., 2016), structure (Eckert and Spencer, 1987; NoyMeir, 1979, 1993; Walker and Noy-Meir, 1982), goods and services (Papanastasis et al., 2015), functionality (White, 1979; Sousa, 1984; Hobbs and Huenneke, 1992), soil erosion (Tadesse and Penden, 2002; Palacio et al., 2014; Mekuria and Aynekulu, 2013), nutrient cycling (Frank et al., 1998; Ritchie and Tilman, 1995; Fernandez et al., 2008), and hydrological processes (Cerdà and Lavee, 1999; Hiernaux et al., 1999; Sharafatmandrad et al., 2010). However, there is evidence that grazing-management activity, not grazing, is the main cause of rangeland degradation in arid and semi-arid environments (Gulelat, 2002). Pastoralism is a traditional rangemanagement activity that focuses mostly on natural forage rather than on cultivated fodder (Sandford, 1983).

Pastoralists usually have a wealth of knowledge about their grazing lands, attained through years of observations and experiences in herding practices (Oba and Kotile, 2001; Mapinduzi et al., 2003). To combat rangeland degradation, it is recommended that rangeland management systems integrate community perceptions and practices (Khwarae, 2006). Thus, the indigenous knowledge of the local communities can be used in conjunction with technical knowledge to manage natural resources (Khwarae, 2006). In many developing countries where rangelands are a dominant land type and are critically important in the livelihoods of a significant portion of the population, severe rangeland degradation can create significant social, economic, and environmental problems (Bedunah and Angerer, 2012). Therefore, scientific and indigenous knowledge should be integrated so that local communities are able to realize their capacity for monitoring and responding to the land degradation and environmental changes (Stringer and Reed, 2007). The resulting system for rangeland management would improve community livelihood and decrease rangeland degradation at the same time (Khwarae, 2006). It is interesting that pastoralists and ecologists unanimously agree on most of the rangeland degradation indicators.

If land managers want rangeland-degradation indicators to be applicable to land management, then they must be easy to use by local communities, accurate to assess environmental sustainability, and they must result in conservation (Reed et al., 2008). On the other hand, the involvement of the pastoralists in planning and implementing land conservation programs require conservationists and technicians to be aware of environmental indicators used by pastoralists for assessing rangeland degradation. There are many studies that convey a combination of local and scientific ecological knowledge that may contribute to easy and accurate monitoring and management of natural resource changes by local communities (e.g. Folke et al., 2002; Thomas and Twyman, 2004; Fraser et al., 2006; Reed et al., 2007, 2008).

Bottom-up or local-participation approaches implicate that pastoralists have accumulated a wealth of knowledge over time, based on long-term experiences that can complement scientific knowledge concerning environmental assessment and conservation (Richards, 1980). Recently it has become known that both indigenous knowledge and local management play an important role in natural resource conservation (Warren, 1992; Berkes et al., 2000) and combat land degradation. Additionally, there is growing interest concerning how indigenous ecological knowledge and management practices can be used in collaboration with standard scientific methods for improved understanding of the environment and its changes (Dahlberg, 2000; Reed et al., 2007).

The history of pastoralism in Iran dates back several thousand years, but indigenous ecological knowledge of pastoralism is neglected in most studies related to rangelands. Therefore, our main objective was to evaluate pastoralists' knowledge of rangeland degradation assessment, based on their perceptions and experiences. Our research questions were the following.

a. What are the pastoralists' land evaluation criteria?

b. What indicators do the pastoralists use for degradation assessment?

c. Is there a possibility of combining scientific land degradation indicators with those of the pastoralists in order to assess rangeland degradation?

\section{Materials and methods}

\subsection{Study area}

The sites used for this study are parts of Golestan National Park located in Golestan Province in north-eastern Iran. The park was established in 1957 as the first national park and biosphere reserve of the Middle East. Golestan National Park spans an area of $872.4 \mathrm{~km}^{2}$, comprising Caspian forests, steppe rangelands and the Juniper woodlands. The two rangeland sites selected for this study were Mirza Baylu $\left(37^{\circ} 19^{\prime} 29^{\prime \prime}-37^{\circ} 21^{\prime} 35^{\prime \prime} \mathrm{N}\right.$ and $56^{\circ} 13^{\prime} 56^{\prime \prime}-$ $56^{\circ} 19^{\prime} 20^{\prime \prime} \mathrm{E} ; 1248-1310 \mathrm{~m}$ a.s.l.) and Dasht $\left(37^{\circ} 18^{\prime \prime} 12^{\prime \prime}-\right.$ $37^{\circ} 19^{\prime} 37^{\prime \prime} \mathrm{N}$ and $56^{\circ} 13^{\prime}-56^{\circ} 1^{\prime} 33^{\prime \prime} \mathrm{E}$; $993-1058 \mathrm{~m}$ a.s.l.). In each site, grazing parts outside the park are separated from the exclosure parts inside the park by a narrow road (Fig. 1).

The Dasht site is located in the southern part of the Golestan National Park. Most of the site is hilly but there are also a few flat areas. The mean annual precipitation and 


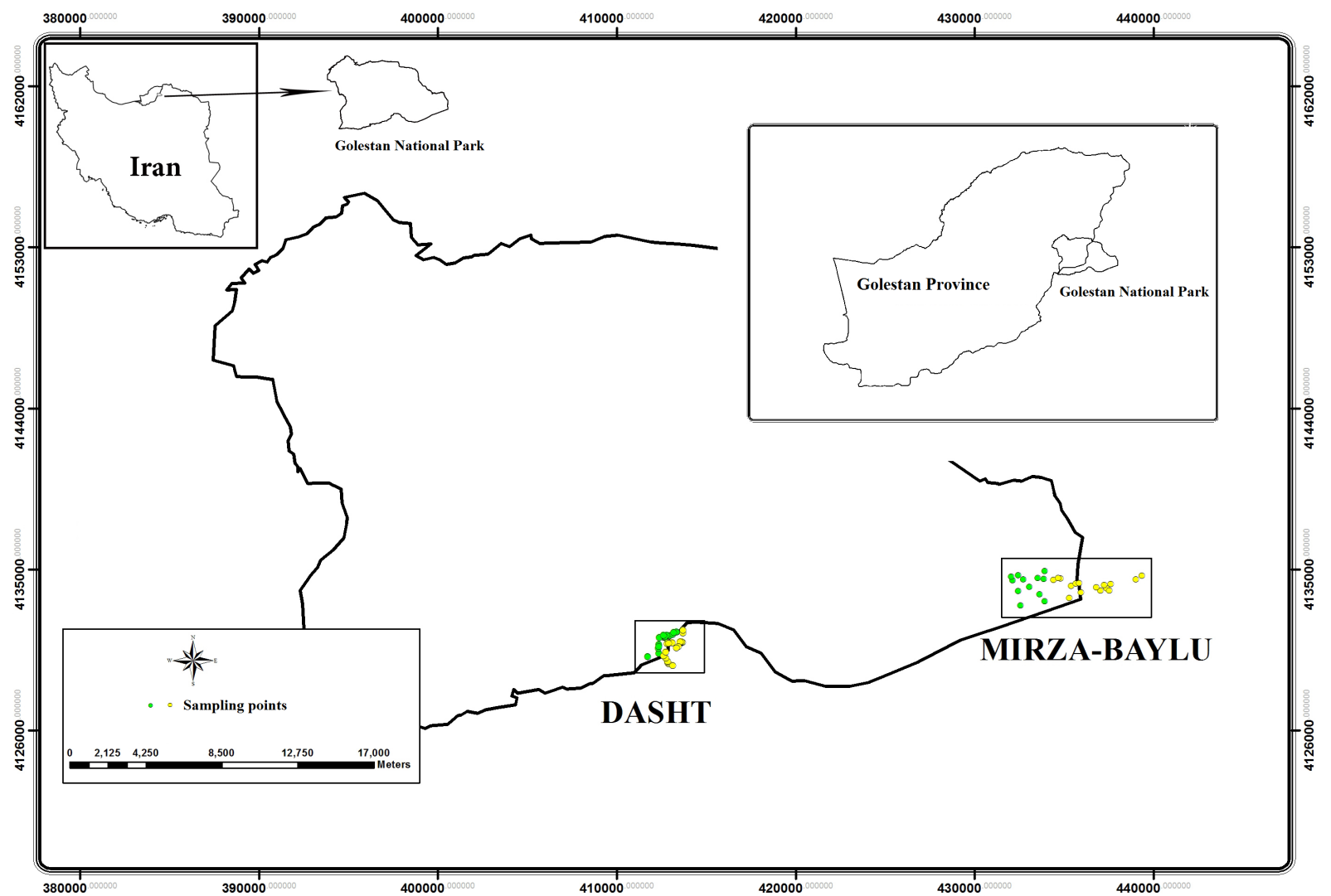

Figure 1. Map of study area in Golestan National Park, Golestan Province, Iran. Dasht is located in the southern part of the park and Mirza Baylu is located in the eastern part of the park. The points are sampling plots.

the mean annual temperatures are $191 \mathrm{~mm}$ and $11^{\circ} \mathrm{C}$, respectively. The vegetation of this semi-steppe rangeland is consisting of grasses and shrubs, dominated by grasses, namely Bromus danthonia, Festuca ovina, Eremopyrum bonaepartis and Phleum paniculatum and dwarf shrubs such as Acantholimon pterostegium and Artemisia kopedaghensis (Fig. 2).

Regarding grazing, the inside of the park is only grazed by wildlife, but the area outside of the park is grazed by the pastoralists' herds consisting of sheep and a small number of goats from early morning till afternoon. The herds are in their own rangelands during all seasons specified by the offices of the Directorate of Natural Resources. Dry forages and agricultural residuals (straw and hay) are used as winter forage for livestock in the both study sites.

The Mirza Baylu site is located at the eastern part of the park and is mostly flat, with slopes less than $5 \%$, and some hilly lands can be seen just in a few parts. The mean annual temperature is $12.9^{\circ} \mathrm{C}$. The study site receives about $236 \mathrm{~mm}$ of annual precipitation. The site is dominated by relatively pure stands of the dwarf shrub Artemisia sieberi accompanied by some grasses. There are some saline parts in the site that are mostly occupied by halophytes such as Salsola dendroides, Phragmites australis, Suaeda physophora and An- abasis aphylla. Also some rare species can be seen in the plains (e.g. Diaphanoptera stenocalycina; Fig. 2).

\subsection{Land degradation assessment}

\subsubsection{Selection of indicators}

The pastoralists' first encounter is generally plagued by suspicion and fear because of government regulatory restrictions on rangeland use. First, we tried to build a foundation of trust by connecting with educated pastoralists, volunteering our personal information, and showing interest in the pastoralism and lifestyle; this was completely effective. Second, pastoralists were notified how important their knowledge is; and no research in the region will be fulfilled without their viewpoints and contributions. Therefore, the study and its objectives were explained for pastoralists to make sure that they are convinced how effective the results of the study in their profession and economic status, rangelands health assessment, and management would be.

Descriptive research was used to obtain information. Therefore, data were collected using both the documentary and field survey. By being present between the pastoralists, we have tried to gather data through participatory techniques and the focus group discussion (FGD) method (Mor- 


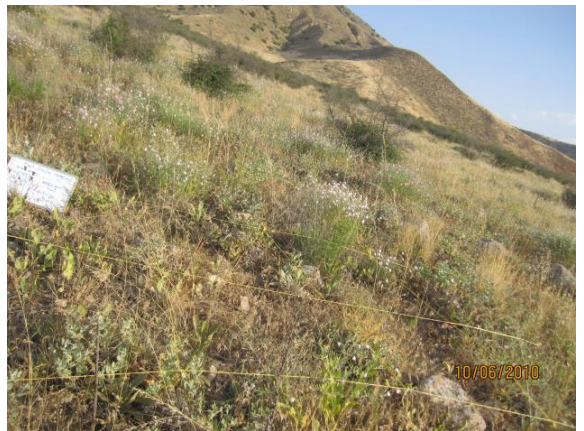

Dasht: inside the park

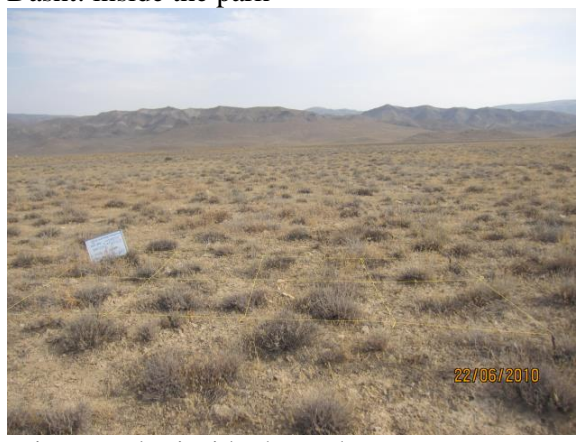

Mirza-Baylu: inside the park

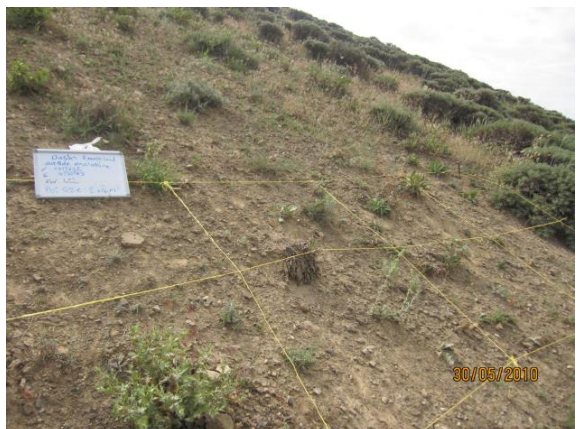

Dasht: outside the park

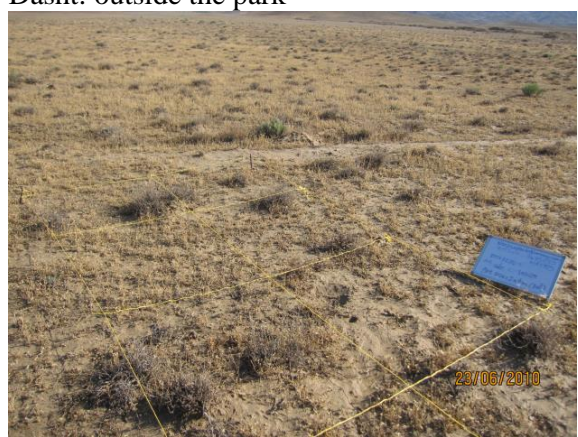

Mirza-Baylu: outside the park

Figure 2. View of vegetation in the study area.

gan, 1988), directive interviews, and the narrative threads of the key and experienced persons. Through meetings as well as individual and group interviews, pastoralists were asked about their ecological knowledge about the indicators of rangeland degradation and the assessment thereof. The most important part of the study was to discuss with interviewees the importance of the pastoralist ecological knowledge on recognition of rangeland degradation and its assessment. To understand how pastoralists assess degradation at landscape level, the key questions were the following. What are the pastoralists' land evaluation criteria? What indicators did the pastoralists use for degradation assessment? What are the roles of the degradation assessment in rangeland health assessment and restoration?

To understand pastoralists' perceptions of land degradation and its influence on rangeland conservation, the questions posed were the following: what do pastoralists think of as a "good" or "bad" rangeland, and what indicators do the pastoralists use as signs of rangeland change from "good" to "bad", for the purposes of rangeland health and management (Roba, 2008)? The results of meetings and interviews were used to identify indicators related to rangeland degradation.

The indicators taken from the literature were discussed in the pastoralists' interviews in their own language and with their own terminology so that they could understand the exact concept of the indicators. As it was expected, most of them had the same indicators as those taken from the literature, but they expressed them in their own language. Therefore, the duplicates were removed, and the new ones were added to the list. A structured questionnaire was designed based on the identified indicators to obtain data on rangeland degradation according to the Land Degradation Assessment in Drylands (LADA, 2009). Therefore, the indicators were assessed on a five-point Likert-type scale ranging from very poor $(0-20)$ to very good (80-100). Qualitative scale was used because of being more intuitive and easier to understand for pastoralists.

\subsubsection{Field assessment}

For the Dasht site, 33 quadrats of $8 \mathrm{~m}^{2}$ in size were randomly located throughout the region: 15 quadrats inside and 18 quadrats outside the park. For the Mirza Baylu site, 28 quadrats of $8 \mathrm{~m}^{2}$ in size were randomly located throughout the region: 12 quadrats inside and 16 quadrats outside the park. Each quadrat was assessed by the three selected pastoralists (i.e. there were three replications). In total, 99 and 84 questionnaires were respectively filled for Dasht (45 inside and 54 outside of the park) and the Mirza Baylu (36 inside and 48 outside of the park) sites. The pastoralists ranked the rangeland degradation indicators in each of the quadrats.

\subsection{Data analyses}

Each pastoralist was considered as a replication. MannWhitney test was used for both sites as total to see if there are any differences between inside and outside the park. Indicators were then compared for each site separately to see if 
Table 1. Identified rangeland degradation indicators based on literature and indigenous ecological knowledge. Indicators related to each category are shown with a check mark.

\begin{tabular}{|c|c|c|c|c|}
\hline Attributes & Indicators & Literature & $\begin{array}{c}\text { Dasht } \\
\text { pastoralists }\end{array}$ & $\begin{array}{l}\text { Mirza Baylu } \\
\text { pastoralists }\end{array}$ \\
\hline Vegetation & $\begin{array}{l}\text { Decrease of vegetation yield } \\
\text { Loss of phyto-diversity } \\
\text { Removal of palatable plants } \\
\text { Increase in poisonous plants } \\
\text { Decrease of shrubs } \\
\text { Increase in annual plants } \\
\text { Increase in the distance between plants } \\
\text { Decrease of plants height } \\
\text { Loss of litter mass }\end{array}$ & $\begin{array}{l}\sqrt{ } \\
\sqrt{ } \\
\sqrt{ } \\
\sqrt{ } \\
\sqrt{ } \\
\sqrt{ } \\
\sqrt{ } \\
\sqrt{ } \\
\sqrt{ }\end{array}$ & $\begin{array}{l}\sqrt{ } \\
\sqrt{ } \\
\sqrt{ } \\
\sqrt{ }\end{array}$ & $\sqrt{ }$ \\
\hline Soil & $\begin{array}{l}\text { Soil salination } \\
\text { Decrease of ground cover } \\
\text { Soil muddiness } \\
\text { Decrease of soil sandiness } \\
\text { Decrease of soil infiltration } \\
\text { Increase in soil looseness }\end{array}$ & $\begin{array}{l}\sqrt{ } \\
\sqrt{ }\end{array}$ & $\begin{array}{l}\sqrt{ } \\
\sqrt{ }\end{array}$ & $\begin{array}{l}\sqrt{ } \\
\sqrt{ } \\
\sqrt{ } \\
\sqrt{ } \\
\sqrt{ } \\
\sqrt{ }\end{array}$ \\
\hline Other & $\begin{array}{l}\text { Increased risk of wildfires } \\
\text { Increased risk of pest damage }\end{array}$ & & $\sqrt{ }$ & $\sqrt{ }$ \\
\hline
\end{tabular}

there were any significant differences between two pastoralists' views about land degradation indicators. Minitab (Ver. 16) was used for data analysis.

\section{Results}

Based on a participatory research approach, i.e. integrating ecological knowledge of pastoralists (pastoralists' indicators) and scientific methods (indicators extracted from literature), 17 degradation indicators were identified (Table 1). From 17 indicators, $53 \%$ were classified as vegetative indicators, $35 \%$ were classified as edaphic indicators, and $12 \%$ were classified as other indicators (i.e. indicators related to different aspects of rangelands apart from vegetation and soil). Dasht pastoralists considered nine indicators as the signs of degradation in their rangelands, and five of them $(56 \%)$ were considered to be vegetation indicators. Therefore it can be said that Dasht pastoralists focus more on the vegetation indicators than the soil and other indicators. In contrast, Mirza Baylu pastoralists give more importance to soil indicators. They also considered nine indicators to be the signs of degradation, they considered six of them $(67 \%)$ to be soil indicators. One indicator was considered by both site pastoralists as a sign of land degradation (i.e. "increase in soil looseness"). To test the soil looseness, pastoralists hold soil crusts between the index finger and thumb. They believe that soil of the rangelands in good condition breaks more easily. One indicator, namely the "increased risk of wildfires", was exclusively mentioned by Dasht pastoralists and three indicators including "soil muddiness", "decrease of soil sandi- ness", and "increased risk of pest damage" were exclusively mentioned by Mirza Baylu pastoralists. Muddy soils occur in some parts of rangelands with low productivity potential where infiltration rate is low and soil becomes waterlogged. These areas are not suitable for pastoral settlement in wet season. In the Mirza Baylu site, there are large areas on some hills outside of the park that show signs of pests (a certain type of mouse) feeding on the plants roots and making holes in the surface of the soil.

Based on questionnaires filled out by pastoralists, there were significant differences between inside and outside the park for 10 indicators (Table 2). Most significant indicators were vegetative indicators (eight indicators), and only two of them were edaphic indicators. These results show that pastoralists' perceptions of land degradation were mostly based on soil and vegetation conditions. Pastoralists first described rangeland degradation in terms of vegetation indicators. According to pastoralists' assessment, most indicators had the same median inside and outside the park. But the indicators "increase in poisonous plants" and "soil salination" had lower scores inside the park, while "increase in annual plants", "loss of litter mass", and "increased risk of wildfires" had higher scores inside the park (Table 2). The areas with high grazing pressure and lower productivity potential were presumed to have more annual plants. This is in contrast with the results. It can be related to high grazing pressure outside the park that removed annual plants. The amount of litter and the risk of wildfire will increase in areas with more annual plants; therefore "increased risk of wildfires" and "loss 
Table 2. Comparison of degradation indicators between inside and outside the park for both sites as total. $P$ values below 0.05 are in bold.

\begin{tabular}{lccc}
\hline Indicators & $\begin{array}{c}\text { Median inside of } \\
\text { the park }\end{array}$ & Median outside of the park & $P$ \\
\hline Decrease of vegetation yield & 3 & 3 & $\mathbf{0 . 0 0 5}$ \\
Loss of phyto-diversity & 3 & 3 & $\mathbf{0 . 0 0 5}$ \\
Removal of palatable plants & 3 & 3 & $\mathbf{0 . 0 0 8}$ \\
Increase in poisonous plants & 4 & 5 & $\mathbf{0 . 0 0 1}$ \\
Decrease of shrubs & 3 & 3 & 0.312 \\
Increase in annual plants & 3 & 2 & $\mathbf{0 . 0 0 1}$ \\
Decrease of ground cover & 3 & 3 & $\mathbf{0 . 0 0 0}$ \\
Increase in the distance between plants & 3 & 3 & $\mathbf{0 . 0 0 0}$ \\
Soil salination & 4 & 5 & $\mathbf{0 . 0 0 0}$ \\
Loss of litter mass & 2 & 3 & $\mathbf{0 . 0 0 0}$ \\
Soil muddiness & 3 & 2 & 0.774 \\
Decrease of plants height & 3 & 3 & 0.167 \\
Decrease of soil sandiness & 3 & 3 & 0.896 \\
Decrease of soil infiltration & 4 & 3 & 0.245 \\
Increase in soil looseness & 2 & 2 & 0.667 \\
Increased risk of wildfires & 2 & 1 & $\mathbf{0 . 0 0 0}$ \\
Increased risk of pest damage & 4 & 4 & 0.138
\end{tabular}

of litter mass", respectively, had higher and lower scores inside the park.

Comparing each site separately revealed somewhat different results (Table 3). Indicators "decrease of ground cover", "increase in the distance between plants", "soil salination", "loss of litter mass", and "increased risk of wildfires" were significant in both sites. Therefore, pastoralists of both sites considered these indicators to be good indicators for assessing and evaluating the degradation of their own rangelands. Vegetation indicators including "decrease of vegetation yield", "loss of phyto-diversity", and "removal of palatable plants" were just significant in the Dasht site. In contrast, the indicators "increase in poisonous plants", "decrease of shrubs", and "increase in annual plants" were just significant in the Mirza Baylu site (Table 3).

As foregoing, in the areas with high grazing pressure and lower productivity potential presumed to have more poisonous and annual plants than perennial forage plants, accordingly indicators "decrease of shrubs" and "increase in poisonous plants" had higher scores outside the park, but "increase in annual plants" had lower scores outside the park in Mirza Baylu site; this is related to high grazing pressure. Pastoralists believed that in the areas with high productivity potential, forage plants are diverse, which itself increases palatability. Therefore, livestock can find various types of forage.

\section{Discussion}

Pastoralists' indigenous ecological knowledge on rangeland management is the result of their historic environmental management over time (Fernandez-Gimenez, 2000). As is generally known, local knowledge is a rich source of information about land degradation, environmental sustainability, and their respective indicators. Local ecological knowledge of pastoralists has the capability to be used for the management of natural resources. This capability will substantially increase if it is linked to a more general scientific understanding (Reed et al., 2008). The current research tried to integrate indigenous ecological knowledge on rangeland degradation with scientific ecological methods. This research shows that pastoralists can realize the biophysical changes in the rangeland ecosystems caused by livestock grazing. Looking more closely into the indicators list, it can be understood that pastoralists' ecological knowledge on rangeland degradation was based on the connection between people, environmental conditions, and ecosystem productivity (Angassa et al., 2012). Considering both sites as complete, pastoralists focus more on the soil indicators than the vegetation and other indicators as the signs of degradation. Therefore they preferred these indicators for the degradation assessment of their own rangelands during the discussions and interviews (Oba, 2012; Reed et al., 2008).

From indicators taken from literature, four vegetation indicators (i.e. "decrease of shrubs", "increase in annual plants", "increase in the distance between plants", and "decrease of plants height") were not considered by pastoralists. These indicators are mostly related to grazing influence on vegetation. As the livelihood of pastoralists depends on rangeland vegetation, they always try to deny the negative effects of high grazing pressure on rangelands.

The indicators "soil muddiness" and "decrease of soil sandiness", which were exclusively mentioned by Mirza Baylu pastoralists, can to some extent be considered the same 
Table 3. Comparison of all identified rangeland degradation indicators between inside and outside the park for each site separately. $P$ below 0.05 are in bold.

\begin{tabular}{|c|c|c|c|c|c|c|}
\hline \multirow[b]{3}{*}{ Indicators } & \multicolumn{6}{|c|}{ Site } \\
\hline & \multicolumn{3}{|c|}{ Dasht } & \multicolumn{3}{|c|}{ Mirza Baylu } \\
\hline & $\begin{array}{l}\text { Median inside } \\
\text { the park }\end{array}$ & $\begin{array}{l}\text { Median outside } \\
\text { the park }\end{array}$ & $P$ & $\begin{array}{l}\text { Median inside } \\
\text { the park }\end{array}$ & $\begin{array}{l}\text { Median outside } \\
\text { the park }\end{array}$ & $P$ \\
\hline Decrease of vegetation yield & 3 & 3 & 0.002 & 3 & 4 & 0.501 \\
\hline Loss of phyto-diversity & 3 & 3 & 0.000 & 3 & 4 & 0.694 \\
\hline Removal of palatable plants & 3 & 4 & 0.000 & 3 & 4 & 0.628 \\
\hline Increase in poisonous plants & 5 & 5 & 0.468 & 4 & 5 & 0.000 \\
\hline Decrease of shrubs & 3 & 3 & 0.548 & 3 & 4 & 0.028 \\
\hline Increase in annual plants & 3 & 3 & 0.127 & 3 & 2 & 0.001 \\
\hline Decrease of ground cover & 2 & 2 & 0.037 & 4 & 3 & $\mathbf{0 . 0 0 0}$ \\
\hline Increase in the distance between plants & 3 & 3 & 0.000 & 4 & 3 & 0.002 \\
\hline Soil salination & 5 & 5 & 0.011 & 4 & 5 & 0.005 \\
\hline Loss of litter mass & 3 & 2 & 0.001 & 3 & 2 & 0.000 \\
\hline Soil muddiness & 2 & 3 & 0.151 & 4 & 4 & 0.238 \\
\hline Decrease of plants height & 3 & 3 & 0.558 & 3 & 3 & 0.977 \\
\hline Decrease of soil sandiness & 3 & 3 & 0.891 & 2 & 3 & 0.937 \\
\hline Decrease of soil infiltration & 3 & 3 & 0.671 & 4 & 4 & 0.250 \\
\hline Increase in soil looseness & 3 & 3 & 0.853 & 2 & 2 & 0.665 \\
\hline Increased risk of wildfires & 2 & 2 & 0.032 & 2 & 1 & 0.000 \\
\hline Increased risk of pest damage & 4 & 4 & 0.241 & 4 & 5 & 0.150 \\
\hline
\end{tabular}

as the indicators related to erosion in scientific literature such as "soil surface resistance to erosion", "soil surface loss or degradation", and "compaction layer" (Pellant et al., 2005).

In the present study, in the Mirza Baylu site, before field assessments and during discussions and interviews, pastoralists believed that there is no clear difference between the areas inside and outside of the park. They believed that to some extent, the area outside the park has better condition and less degradation. They believed livestock grazing makes the plants grow faster and leads to more vegetation diversity, freshness and palatability. In contrast, after field assessments, they had evaluated inside the park to have better condition than outside the park based on their own given scores to the indicators. It shows the difference between holistic and detailed assessments of pastoralists based on the indicators scoring in this area. This can be studied more deeply in further research.

Pastoralists of the Dasht site believed that increased risk of wildfires is a sign of an upward trend in the rangeland condition and indicate the increase in vegetation cover. In fact, pastoralists focus more on ecologic aspect of wildfires.

Based on the results in both sites, the rangelands outside the park, especially the areas around the villages, were degraded in comparison to inside the park. Pastoralists focus on soil indicators in assessing rangeland degradation. During the discussion with pastoralists, it was obvious that they are not seeing indicators related to livestock and their emphasis was given to vegetation, soil, and other indicators. Therefore, this gap can be clearly seen in the indicators list. All pastoral- ists must be fully involved in planning and managing strategies; they are knowledgeable about the grazing habits of the livestock and the vegetation of their environment and rangelands (Abate et al., 2010). Indigenous knowledge can provide possibility of rapid assessment of rangeland condition (Oba, 2012). Range scientists become more familiar with indigenous knowledge, its concepts and functions (Mapinduzi et al., 2003).

Generally, there are different approaches for assessing land degradation worldwide. There is no single best method to assess land degradation. Many researchers and scientists emphasize that land degradation assessment can be complex because multiple components of degradation may occur in any one place. Therefore, complexity makes it impossible to use the same tools, techniques, and methods for assessing different components of degradation. Many methods have been improved and justified to gather as much useful data as possible. However, the development of any method requires people with good understanding of ecosystems and the socioeconomic drivers of land degradation. Developing and using simple but yet robust methods (e.g. classes of $1-5$, very good to bad; simple indicators) are good because they can be easily adapted and used even by non-experts (Kapalanga, 2008). This helps in comparing areas, involves stakeholders as much as possible, and aids in land use and restoration planning and projects prioritizing (Kapalanga, 2008). 


\section{Conclusions}

The local pastoralists in the both study sites had the knowledge of land degradation assessment in their own rangelands. Pastoralists have many reasons for portraying their own indicators as more practical for rangeland assessments. The pastoralists have a broad knowledge base covering materials from rangelands vegetation and animal habits to land characteristics. Controlling degradation in grazing lands without considering the people whose their livelihoods depend on them will lead to imperfect results. Therefore, matching the scientific land degradation indicators with the ones pastoralists believe in and understand can lead to the successfully control of land degradation. The involvement of pastoralists and the documentation of their knowledge on rangelands can prove to be useful bases for sustainable utilization and the conservation of natural rangelands. We believe that such plans based on indigenous knowledge can be easily accepted by local people.

Acknowledgements. The authors thank Artemi Cerdà (handling topical editor) for his positive view on the paper and all his help and guidance. We also thank several anonymous reviewers for help in improving the paper.

Edited by: A. Cerdà

\section{References}

Abate, T., Ebro, A., and Nigatu, L.: Traditional rangeland resource utilization practices and pastoralists' perceptions on land degradation in south-east Ethiopia, Trop. Grasslands, 44, 202-212, 2010.

Angassa, A.: Effects of grazing intensity and bush encroachment on herbaceous species and rangeland condition in southern Ethiopia, Land Degrad. Dev., 25, 438-451, 2014.

Angassa, A., Oba, G., and Stenseth, N. C.: Community-based Knowledge of Indigenous Vegetation in Arid African Landscapes, Consilience: The Journal of Sustainable Development, 8, 70-85, 2012.

Bedunah, D. J. and Angerer, J. P.: Rangeland Degradation, Poverty, and Conflict: How Can Rangeland Scientists Contribute to Effective Responses and Solutions?, Rangeland Ecol. Manag., 65, 606-612, doi:10.2111/REM-D-11-00155.1, 2012.

Berendse, F., van Ruijven, J., Jongejans, E., and Keesstra, S. D.: Loss of plant species diversity reduces soil erosion resistance of embankments that are crucial for the safety of human societies in low-lying areas, Ecosystems, 18, 881-888, doi:10.1007/s10021015-9869-6, 2015.

Berkes, F., Colding, J., and Folke, C.: Rediscovery of traditional ecological knowledge as adaptive management, Ecol. Appl., 10, 1251-1262, doi:10.1890/10510761(2000)010[1251:ROTEKA]2.0.CO;2, 2000.

Branson, F. A., Gifford, G. F., Renard, K. G., and Hadley, R. F.: Preface, in: Rangeland hydrology, edited by: Reid, E. H., Soci- ety For Range Management, Kendall/Hunt Publishing Company, Second Edition, 339 pp., 1981.

Brevik, E. C., Cerdà, A., Mataix-Solera, J., Pereg, L., Quinton, J. N., Six, J., and Van Oost, K.: The interdisciplinary nature of SOIL, SOIL, 1, 117-129, doi:10.5194/soil-1-117-2015, 2015.

Cerdà, A.: Changes in overland flow and infiltration after a rangeland fire in a Mediterranean scrubland, Hydrol. Process., 12, 1031-1042, 1998.

Cerdà, A. and Lavee, H.: The effect of grazing on soil and water losses under arid and Mediterranean climates, Implications for desertification, Pirineos, Revista de Ecología de Montaña, 153154, 1999.

Dahlberg, A. C.: Interpretations of environmental change and diversity: a critical approach to indications of degradation - the case of Kalakamate, Northeast Botswana, Land Degrad. Dev., 11, 549562, 2000.

Eckert, R. E. and Spencer, J. S.: Growth and reproduction of grasses heavily grazed under rest-rotation management, J. Range Manage., 40, 156-159, 1987.

Fernandez, D. P., Neff, J. C., and Reynolds, R. L.: Biogeochemical and ecological impacts of livestock grazing in semi-arid southeastern Utah, USA, J. Arid Environ., 72, 777-791, 2008.

Fernandez-Gimenez, M. E.: The role of Mongolian nomadic pastoralists' ecological knowledge in rangeland management, Ecol. Appl., 10, 1318-1326, doi:10.1890/10510761(2000)010[1318:TROMNP]2.0.CO;2, 2000.

Folke, C., Carpenter, S., Elmqvist, T., Gunderson, L., Holling, C. S., and Walker, B. H.: Resilience and sustainable development: building adaptive capacity in a world of transformations, Ambio, 31, 437-440, 2002.

Frank, D. A., McNaughton, S. J., and Tracy, B. F.: The ecology of the Earth's grazing ecosystems, Bioscience, 48, 513-521, 1998.

Fraser, E. D. G., Dougill, A. J., Mabee, W. E., Reed, M. S., and McAlpine, P.: Bottom up and top down: analysis of participatory processes for sustainability indicator identification as a pathway to community empowerment and sustainable environmental management, Environ. Manage., 78,114-127, 2006.

Gulelat, W.: Household herd size among Pastoralists in relation to overstocking and rangeland degradation, International institute for geo-information science and earth observation, Enschede, the Netherlands, 2002.

Hiernaux, P., Bielders, C. L., Valentin, C., Bationo, A., and Fernandez-Rivera, S.: Effects of livestock grazing on physical and chemical properties of sandy soils in Sahelian rangelands, J. Arid Environ., 41, 231-245, 1999.

Hobbs, R. J. and Huenneke, L. F.: Disturbance, diversity and invasion: implications for conservation, Conserv. Biol., 6, 324-337, 1992.

IFAD.: Combating range degradation: The Experience of IFAD (International Fund for Agricultural Development), available at: http://www.ifad.org/lrkm/theme/range.htm (last access: 13 April 2016), 2003.

Kapalanga, T. S.: A review of land degradation assessment methods, Land restoration training program, Keldnaholt, Reykjavic, Iceland, 2008.

Keesstra, S. D., Geissen, V., van Schaik, L., Mosse., K., and Piiranen, S.: Soil as a filter for groundwater quality, Current Opinions in Environmental Sustainability, 4, 507-516, doi:10.1016/j.cosust.2012.10.007, 2012. 
Khwarae, G.: Community perceptions of rangeland degradation and management systems in Loologane and Shadishadi, Kweneng North, Botswana, Department of International Environment and Development Studies, Norway, 2006.

Kröpfl, A. I., Cecchi, G. A., Villasuso, N. M., and Distel, R. A.: Degradation and recovery processes in Semi-Arid patchy rangelands of northern Patagonia, Argentina, Land Degrad. Dev., 24, 393-399, doi:10.1002/ldr.1145, 2011.

LADA: LADA project document, Field manual for local level land degradation assessment in dry lands, FAO, available at: http://www.fao.org/nr/kagera/tools-and-methods/ lada-local-level-assessment-manuals (last access: 13 April 2016), 2009.

Li, X.-L., Gao, J., Brierley, G., Qiao, Y. -M., Zhang, J., and Yang, Y.-W.: Rangeland degradation on the Qinghai-Tibet plateau: Implications for Rehabilitation, Land Degrad. Dev., 24, 72-80, doi:10.1002/ldr.1108, 2013.

Mapinduzi, A. L., Oba, G., Weladji, R. B., and Colman, J. E.: Use of indigenous ecological knowledge of the Maasai pastoralists for assessing rangeland biodiversity in Tanzania, Afr. J. Ecol., 41, 329-336, doi:10.1111/j.1365-2028.2003.00479.x, 2003.

Mekuria, W. and Aynekulu, E.: Exclosure land management for restoration of the soils in degraded communal grazing lands in Northern Ethiopia, Land Degrad. Dev., 24, 528-538, doi:10.1002/ldr.1146, 2013.

Morgan, D. L.: Focus Group as Qualitative Research, Sage, UK, 1988.

Noy-Meir, I.: Structure and function of desert ecosystems, Israel, J. Bot., 28, 1-19, 1979.

Noy-Meir, I.: Compensating growth of grazed plants and its relevance to the use of rangelands, Ecol. Appl., 3, 32-34, 1993.

Oba, G.: Harnessing pastoralists' indigenous knowledge for rangeland management: three African case studies, Pastoralism: Research, Policy and Practice, 2, doi:10.1186/2041-7136-2-1, 2012.

Oba, G. and Kotile, D. G. Assessments of landscape level degradation in southern Ethiopia: pastoralists vs ecologists, Land Degrad. Dev., 12, 461-475, doi:10.1002/ldr.463, 2001.

Palacio, R. G., Bisigato, A. J., and Bouza, B. J.: Soil erosion in three grazed plant communities in northeastern Patagonia, Land Degrad. Dev., 25, 594-603, doi:10.1002/ldr.2289, 2014.

Papanastasis, V. P., Bautista, S., Chouvardas, D., Mantzanas, K., Papadimitriou, M., Mayor, A. G., Koukioumi, P., Papaioannou, A., and Vallejo, R. V.: Comparative assessment of goods and services provided by grazing regulation and reforestation in degraded Mediterranean rangelands, Land Degrad. Dev., doi:10.1002/ldr.2368, online first, 2015.

Pellant, M., Shover, P., Pyke, D., and Herrick, J. E.: Interpreting indicators of rangeland health. Version 4. Interagency Technical Reference 1734-6, Bureau of Land Management, Denver, Colorado, USA, 2005.

Reed, M. S., Dougill, A. J., and Taylor, M. J.: Integrating local and scientific knowledge for adaptation to land degradation: Kalahari rangeland management options, Land Degrad. Dev., 18, 249268, doi:10.1002/ldr.777, 2007.

Reed, M. S, Dougill, A. J, and Baker, T. R.: Participatory indicator development: what can ecologists and local communities learn from each other? Ecol. Appl., 18, 1253-1269, doi:10.1890/070519.1, 2008.
Richards, P.: Community environmental Knowledge in African Rural Development, in: Indigenous Knowledge Systems and Development, edited by: Brokensha, D., Warren, D. M., and Werner, O., University Press of America, New York, 181-194, 1980.

Ritchie, M. E. and Tilman, D.: Responses of legumes to herbivores and nutrients during succession on a nitrogen-poor soil, Ecology, 76, 2648-2655, 1995.

Roba, H. G.: Global goals, local actions: A framework for integrating indigenous knowledge and ecological methods for rangeland assessment and monitoring in northern Kenya, Doctoral Thesis, Department of International Environment and Development Studies, Noragric Norwegian University of Life Sciences (UMB), 2008.

Sandford, S.: Management of pastoral development in the Third World, Overseas Development Institute, London, 1983.

Sharafatmandrad, M., Mesdaghi, M., Bahremand, A., and Barani, H.: The role of litter in rainfall interception and maintenance of superficial soil water content in an arid rangeland in Khabr National Park in south-eastern Iran, Arid Land Res. Manag., 24, 213-222, 2010.

Sharafatmandrad, M., Sepehry, A., and Barani, H.: Plant Species and Functional Types' Diversity in Relation to Grazing in Arid and Semi-arid Rangelands, Khabr National Park, Iran, Journal of Rangeland Science, 4, 203-214, 2014.

Sousa, W. P.: The role of disturbance in natural communities, Annu. Rev. Ecol. Syst., 15, 353-391, 1984.

Stringer, L. C. and Reed, M. S.: Land degradation assessment in southern Africa: Integrating local and scientific knowledge bases, Land Degrad. Dev., 18, 99-116, 2007.

Tadesse, G. and Penden, D.: Livestock grazing impact on vegetation, soil and hydrology in a tropical highland watershed, Proceedings of MoWR/EARO/IWMI/ILRI International Workshop held at ILRI, Addis Ababa, Ethiopia 2-4 December, 2002.

Tarhouni, M., Hmida, W. B., and Neffati, M.: Long-term changes in plant life forms as a consequence of grazing exclusion under arid climatic conditions, Land Degrad. Dev., in press, doi:10.1002/ldr.2407, 2016.

Thomas, D. S. G. and Twyman, C.: Good or bad rangeland? Hybrid knowledge, science and local understandings of vegetation dynamics in the Kalahari, Land Degrad. Dev., 15, 215-231, doi:10.1002/ldr.610, 2004.

Walker, B. H. and Noy-Meir, I.: Aspects of the stability and resilience of savanna ecosystems, in: Ecology of Tropical Savannas, edited by: Huntley, B. J. and Walker, B. H., Springer, Berlin, 556-590, 1982.

Warren, D.: Indigenous knowledge, biodiversity conservation and development, Keynote address at the International Conference on Conservation of Biodiversity in Africa: Local initiatives and institutional roles, 30 August-3 September 1992, Nairobi, Kenya, 1992.

White, P. S.: Pattern, process, and natural disturbance in vegetation, Bot. Rev., 45, 229-299, 1979.

Wilcox, B. P. and Thurow, T. L.: Preface "Emerging issues in rangeland ecohydrology”, Hydrol. Process., 20, 3155-3157, 2006. 